\title{
The Use of Ground-Penetrating Radar to Locate Tree Roots
}

\author{
G.M. Moore and C.M. Ryder
}

\begin{abstract}
Until recently the only way to investigate tree root architecture and distribution involved the physical removal of soil. However, in the past decade, ground-penetrating radar (GPR), which has been used in many other industries for about 30 years, has been used to study tree roots. GPR is relatively new to Australia and the aim of this research was to assess its spatial accuracy and ability to detect tree roots.

Three experiments were conducted using a $900 \mathrm{MHz}$ GPR device (Tree Radar ${ }^{\star}$ ). The first experiment tested the ability of GPR to detect roots of sizes $10 \mathrm{~mm}, 20 \mathrm{~mm}$, and $40 \mathrm{~mm}$ in diameter at depths of $200 \mathrm{~mm}, 400 \mathrm{~mm}$, and $800 \mathrm{~mm}$, while the second experiment tested its capacity to resolve two roots placed close together. Roots of 20-30 mm in diameter were placed in pairs at $20 \mathrm{~mm}, 40 \mathrm{~mm}$, and $80 \mathrm{~mm}$ apart at depths of $200 \mathrm{~mm}, 400 \mathrm{~mm}$, and $800 \mathrm{~mm}$. The final experiment used GPR to analyze the in situ root system of a small Pistacia chinensis (Chinese pistachio) after which the root system was excavated using an AirSpade ${ }^{\star}$ and counts of root numbers were undertaken and compared with the predicted results.

GPR detected and discriminated tree roots accurately at $200 \mathrm{~mm}$ depth, but as the depth increased to $400 \mathrm{~mm}$ and then to $800 \mathrm{~mm}$, the levels of error increased, probably due to the choice of antenna available for the experiments, leading to the presence of phantom roots in some results and the misdetection of true roots in others. Confounding of the signal with unexpected interference or inadequate signal processing was most likely the cause. In the final experiment, GPR missed many small roots in the trenches close to the tree and appeared to detect multiple roots as one. In the outer trenches, GPR predicted 52 roots in total but excavation revealed only one in these disturbed urban soils.

Key Words. Discriminating Roots; Ground-Penetrating Radar; Root Architecture; Root Detection; Tree Radar; Tree Roots.
\end{abstract}

Trees can cause damage to built and hard structures. Between 1988 and 1992, tree-induced subsidence damage to buildings in the United Kingdom exceeded GBP $£ 1.6$ billion (Lawson and O’Callaghan 1995), while in the United States of America, a survey of cities estimated that annual concrete and sewer-line repair bills due to tree-related damage amounted to USD \$4.28 per tree, which constituted approximately $25 \%$ of the annual tree budgets for the cities (Coder 1998). Much of the damage attributed to trees, may be the result of poor workmanship and faulty services installation (Cutler 1995; Ståhl and Rolf 1998), but tree root growth is considered by many local government managers to be an expensive nuisance and a significant liability risk (Coder 1998).

Orientation of the structural roots of a tree and inspection of the root crown have provided indications of where the roots may be (Harris et al.
1999). However, in the past, the roots have had to be excavated manually using digging equipment and/or archaeological techniques (Melhuish 1968). Physical removal of soil was the only way to accurately map tree roots, making tree root investigation costly, labor intensive, time-consuming, and often, if not always, destructive of the roots being investigated. Other options for investigation have included using high-pressure water or air (AirSpade ${ }^{\circledast}$ ) to blast the rooting area free from soil.

For trees growing in urban situations, most of the roots are close to the surface, and if the soil is compacted, the roots will tend to remain near the surface (Craul 1992). Even where soils are not compacted, studies have shown that the bulk of tree roots are usually found in the top 500-1000 mm of soil (Havis 1938; Hitchmough 1994; Watson 1995; Akinnifesi et al. 1999; Peter and Lehmann 2000; Sydnor et al. 
2000) and commonly extending to $2-3$ times the dripline or 1-2 times the height of the tree (Perry 1982; Pirone et al. 1988; Schnelle et al. 1989; Hitchmough 1994). Perry (1982) suggests that roots may extend up to seven times the diameter of the drip line. There are exceptions, with Eucalyptus marginata (Jarrah) having roots that penetrate the soil to $20 \mathrm{~m}$ (Shigo 1991), while Kozlowski (1971) provided evidence of a number of species that have demonstrated deeper rooting, often in response to dry conditions.

Tree roots are opportunistic and tend to grow where soil conditions, such as low bulk density and supplies of oxygen, moisture, and nutrients, are best (Perry 1982). At the point of attachment to the trunk, tree roots are usually few and large (Pirone 1988). These large roots tend to taper rapidly and branch into rope-like strands that can extend for many meters (Perry 1982). When roots encounter favorable conditions, it is common for them to branch many times, creating a fan-like structure to exploit the favorable soil conditions and reserves (Coder 1998).

Ground-penetrating radar (GPR) has been in used for other applications and in other disciplines, such as archaeological investigations, bridge deck analysis, detection of landmines, pipe and cable detection, and planetary exploration for about forty years (Daniels 2004; Gibson and George 2004). Over the past decade, the technology has been applied to mapping tree roots (Hruskra et al. 1999; Cermák et al. 2000; Butnor et al. 2001; Butnor et al. 2003; Barton and Montagu 2004; Guo et al. 2013). Barton and Montagu (2004) attempted to determine the diameters of roots buried in sand with some success, and Hirano et al. (2012), using GPR, found that their system estimated $68 \%$ of the excavated root biomass. Methods are improving, however, and Wu et al. (2014) used GPR to reconstruct three-dimensional coarse root structures with an accuracy of $83 \%$, based on measurements of different size classes of roots from a previously excavated shrub root system. Mapping of general root architecture (Wu et al. 2014) with GPR has proved accurate, as have estimates of root biomass (Cui et al. 2013) and fresh root biomass is more accurately determined than dry root mass (Butnor et al. 2003; Wu et al. 2014). Bassuk et al. (2011) also used GPR to locate tree roots under pavement.

GPR is an electromagnetic technique that can be used to detect physical changes in the medium through which the GPR signals are transmitted. The signals respond to the relative dielectric permittivity, which is a general measurement of how well electromagnetic radiation passes through a medium such as soil (Guo et al. 2013). GPR systems use signal processing both during and after scanning for roots, usually to improve the signal to noise ratio, but such processing is usually done in a way that the arboricultural field user of GPR is unaware of its application (Wielopolski et al. 2000; Butnor et al. 2003; Guo et al. 2013). Raw radargrams are processed so that they clean up and adjust an image so that it can be more readily classified and interpreted for root detection (Guo et al. 2013).

Some soil characteristics, such as texture, bulk density, and water content, can affect the soil's dielectric properties, and so impact upon the use of GPR by making it difficult to contrast roots from the medium in which they occur or by increasing signal reflection (van Dam et al. 2005; Guo et al. 2013; Isaac and Anglaaere 2013). Many GPR studies have been conducted under controlled circumstances where soil conditions have been optimized for GPR use (Cui et al 2013; Guo et al 2013). The best quality of GPR root detection is achieved in well-drained soils under dry conditions (van Dam et al. 2005; Zhu et al. 2011; Guo et al. 2013) and in electrically resistive soils, such as sands (Guo et al. 2013). Soils with less than $30 \%$ volumetric water content give the best contrast between roots and the surrounding soil (Cui et al. 2013). Consequently, soils with a higher sand content are superior to clays for GPR detection of roots, especially as the depth of the roots increases (Guo et al. 2013; Isaac and Anglaaere 2013).

The use of GPR as a non-invasive, non-destructive, and efficient method of locating and mapping roots has advantages that go beyond reducing the unnecessary removal of, or significant root damage to, valuable urban trees (Guo et al. 2013). It allows the scanning of large root systems quickly and economically, does not disturb the soil, allows repeated measurements, and can detect roots under hard surfaces (Bassuk et al. 2011). However, when GPR-generated root maps were compared with actual field observation of the root systems after excavation, there were variations, especially in vertical views that were used to construct a three-dimensional image of the root system (Guo et al. 2013). In many field situations, a planar map of the root system would be 
adequate for arboricultural management purposes as it is easier and quicker to read and interpret.

The use of GPR to map tree roots has been available in Australia for about a decade and is commercially available for arboricultural service companies. However, while there has been increasing use of GPR in root mapping, there have been calls for "ground truthing" studies that establish the limits and resolution for GPR in locating tree roots (Bassuk et al. 2011). Studies have been undertaken comparing GPR-generated root maps with those constructed by laser scanning of excavated roots systems that revealed significant differences from the GPR maps (Stokes et al. 2002; Guo et al. 2013), and natural abundance water isotope tracers have been used as a means of validating GPR-detected root distributions (Isaac and Anglaaere 2013).

There has been concern about the size of roots GPR can accurately detect. Several authors note that GPR is best at detecting relatively thick roots, with roots of greater than $5 \mathrm{~mm}$ diameter considered to be the smallest that can be accurately detected (Zhu et al. 2011; Isaac and Anglaaere 2013). Hirano et al. (2012) detected $54 \%$ of roots greater than $10 \mathrm{~mm}$ in diameter, but only $6.6 \%$ of roots smaller than $10 \mathrm{~mm}$ in diameter. The capacity of GPR to discriminate between two closely aligned objects is influenced by the frequency of the signal used. A $900 \mathrm{MHz}$ GPR device has a capacity to discriminate items that are between 100-200 mm apart (Guo et al. 2013).

This research provides data on the GPR detection of roots at different depths, its capacity to discriminate between roots placed in close proximity at different depths, and its accuracy in mapping the root system of a tree in situ compared with the subsequently excavated root system. The paper provides data that ground truths some aspects of GPR application to arboricultural root location in a situation where soils have been disturbed in a fashion typical of many urban construction and building sites, in contrast to many other studies where GPR has been used under controlled experimental conditions (Guo et al. 2013). Of the 24 papers reviewed by Guo et al. (2013), ten were described as controlled, ten were in plantations, one was in an orchard, and two were described as urban with lawn or pavement. None of these studies were undertaken in a disturbed urban setting.

\section{MATERIALS AND METHODS}

All experiments were conducted at the University of Melbourne, Burnley College, 500 Yarra Boulevard, Richmond, Australia. Experiments 1 and 2 were conducted using live roots of Prunus persica (L) Batsch (common peach). Plans for the removal of these trees had been made earlier, and so the difficulty of sourcing roots for a destructive experiment was overcome. The GPR device used was a Tree Radar $^{\circledast}$ (TRU - 900), which operated at a central frequency of $900 \mathrm{MHz}$ with $100 \%$ bandwidth. The antenna type was a highly damped dipole with baffling between the transmitting and receiving dipoles.

The roots were harvested from the ground by first removing the aboveground parts of the trees with a chain saw and lifting the stumps out of the ground with a Bobcat ${ }^{\circledast}$ skid steer loader. Roots were either cut from the removed stumps or excavated by hand using a fork. Care was taken to reduce damage to tree roots and no damaged root sections were used for the experiments. Following harvest, the roots were sorted into diameter classes and sectioned into pieces approximately $150 \mathrm{~mm}$ long. They were then placed in moistened plastic bags and stored in a refrigerator at $4^{\circ} \mathrm{C}$ for one week prior to use. Their fresh weights did not change over this period. The moisture content of the roots, based on the fresh and dry weights of two root samples, was approximately 78\%.

The soil into which the roots were to be placed, and within which the Pistacia chinensis Bunge (Chinese pistachio) was growing, is typical of the soil surrounding the Yarra River upon which parts of the inner city of Melbourne are constructed and is an alluvial, sandy loam. There were no rocks or stones of substantial size in any of the trenches, and the profile did not vary over the depth from 0 to $800 \mathrm{~mm}$. The bulk density of the soil varied with depth from $1.50 \mathrm{Mg} \mathrm{m}^{-3}$ at the surface $(0-100 \mathrm{~mm})$ to $1.55 \mathrm{Mg}$ $\mathrm{m}^{-3}$ at depths below $300 \mathrm{~mm}$. The soil $\mathrm{pH}$ was 6.29 at the surface $(0-100 \mathrm{~mm})$ and 6.22 at depths below $300 \mathrm{~mm}$, and electrical conductivity was $1.40 \mathrm{dS} \mathrm{m}^{-1}$ at the surface and $1.28 \mathrm{dS} \mathrm{m}^{-1}$ at depths below 300 $\mathrm{mm}$. All soil data were collected prior to excavation.

The trenching technique was used to mimic the disturbed nature of urban soils, especially after inner urban construction and trenching. The soil was carefully placed over the buried roots by hand in successive layers, with gentle tamping of the soil every 100 $\mathrm{mm}$ to ensure that there was no contamination of 
the soil or air voids and was allowed to settle for one week. The soil level was returned to the original contour, and there was no evidence of mounding as the site was levelled to allow the pass of the GPR device. The site in which the Pistacia chinensis was located contained a number of scattered stones in the surface $150 \mathrm{~mm}$, which came from gravel paths and roadways that had once been located near the site.

Scans were undertaken only when soil conditions were dry, and so soil was well below field capacity. There had been only $1.4 \mathrm{~mm}$ of rainfall in the ten days preceding scanning and none in the preceding 24 hours. Such dry soils are considered to be optimal for the use of GPR (van Dam et al. 2005; Zhu et al. 2011) The daily temperatures varied from $18^{\circ} \mathrm{C}$ to $24^{\circ} \mathrm{C}$ over the same period, and the monthly mean was $19.7^{\circ} \mathrm{C}$ (Bureau of Meteorology 2013). The dry conditions made accurate scanning along straight line transects easier and eliminated variation in the height of the scan. The data were subjected to a two tailed paired-sample t-test (Minitab $^{\star}$ Release 14.1). The two-tailed pairedsample t-tests were performed individually for scans 1,2 , and 3 as well as for the average of scans.

From previous studies (Hruška et al. 1999; Wielopolski et al. 2000; Butnor et al. 2001; Butnor et al. 2003; Barton and Montagu 2004; Bassuk et al. 2011), GPR has been shown to be able to detect subsurface roots. Experiment 1 aimed to investigate the capacity of GPR to detect a single root at different depths, while Experiment 2 investigated the detection and resolution of two roots that were close together. The first experiment investigated detection of roots of $10 \mathrm{~mm}$, $20 \mathrm{~mm}$, and $40-50 \mathrm{~mm}$ in diameter placed at the bottom of vertical trenches of depths of 200 $\mathrm{mm}, 400 \mathrm{~mm}$, and $800 \mathrm{~mm}$ (Figure 1). The upper limit of $40-50 \mathrm{~mm}$ diameter was chosen as it is reported that this size should be detected (Hruška et al. 1999; Butnor et al. 2001; Barton and Montagu 2004). There is some conjecture about how small a root can be detected (Bassuk et al. 2011), as decisions about and specifications for technical aspects, such as antenna frequency can alter the resolution of the GPR in use (Daniels 1996; Daniels 2004). The lower limit of $10 \mathrm{~mm}$ was used, as it is questionable as to whether a root smaller than this would be of arboricultural relevance in terms of interaction with urban infrastructure.
In the second experiment, pairs of roots $20-30$ $\mathrm{mm}$ in diameter were placed in the trench at distances of $20 \mathrm{~mm}, 40 \mathrm{~mm}$, and $80 \mathrm{~mm}$ apart to see whether the GPR could distinguish between the two roots or identified them as a single root (Figure 2). Three replicates of root sections for both Experiments 1 and 2 were buried in narrow $(300$ $\mathrm{mm}$ ), purpose-dug trenches at depths of $200 \mathrm{~mm}$, $400 \mathrm{~mm}$, and $800 \mathrm{~mm}$ (Figure 3). The lower limit of $800 \mathrm{~mm}$ was chosen as roots in urban soils are usually located in the upper profiles of the soil. The GPR device used in these experiments had a lower limit of $1000 \mathrm{~mm}$ due to its configuration and the use of the $900 \mathrm{Mhz}$ antenna, so $800 \mathrm{~mm}$ was within

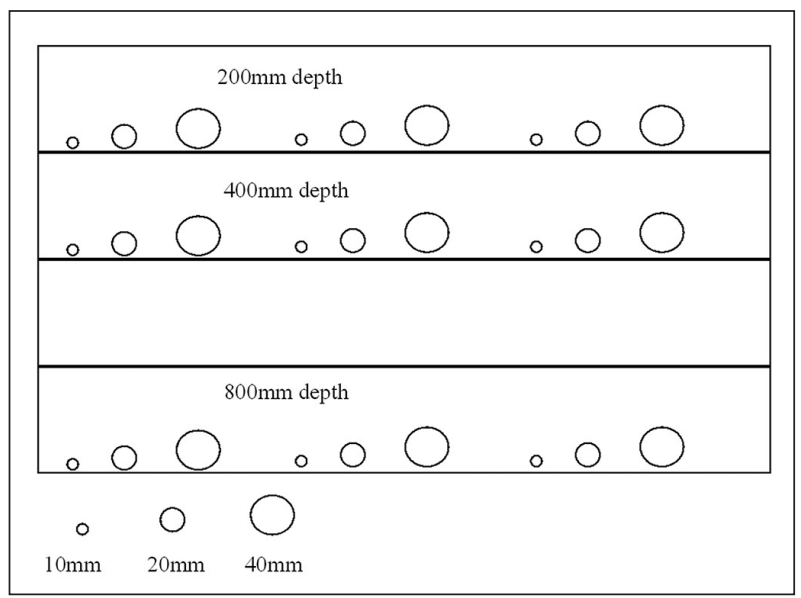

Figure 1. Experimental design for the first experiment. The different sized circles depict root diameters.

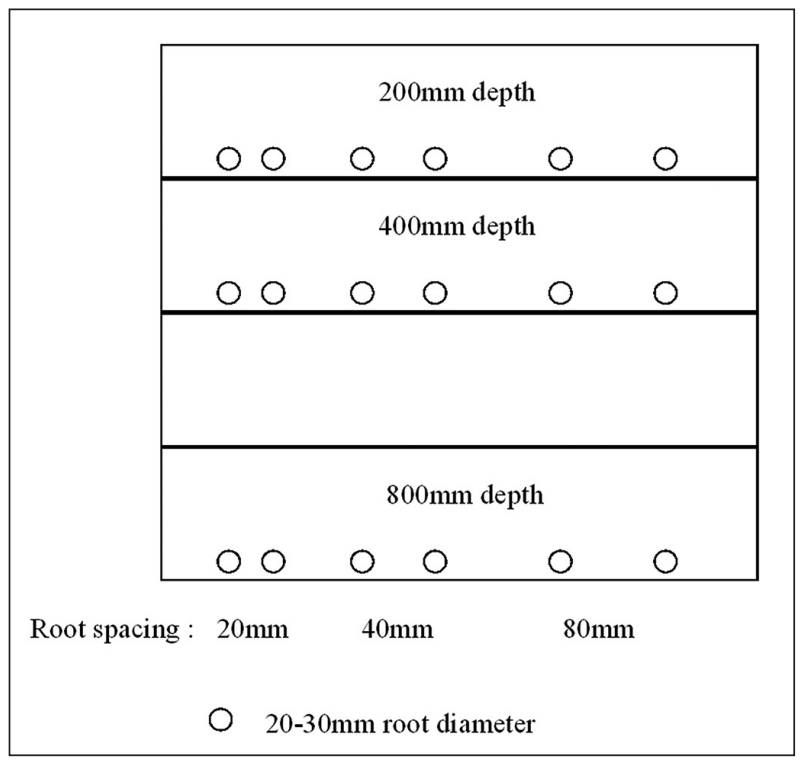

Figure 2. Experimental design for the second experiment. The distance between the paired roots was $200 \mathrm{~mm}$. 


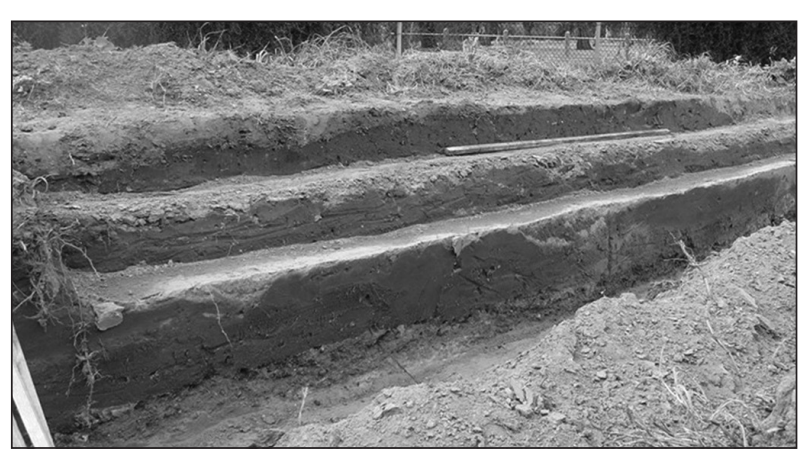

Figure 3. Prepared stepped trenches for Experiments 1 and 2 at $200 \mathrm{~mm}, 400 \mathrm{~mm}$, and $800 \mathrm{~mm}$ depth.

its range. The trenches were offset from each other to ensure that the roots could not overlap between the different depths. The trench was refilled and GPR scans were conducted within seven days of the roots being placed in the ground to reduce the risk of desiccation. After the roots were put in place and buried, the soil surface was made level and the ground marked to show a line perpendicular to the buried roots along which to scan.

The site was scanned by wheeling the cart across the ground, with the GPR device emitting a radar pulse every $5 \mathrm{~mm}$. All three replicates of both experiments were scanned in one pass over the ground and this was repeated three times to determine the consistency of GPR root location. For each pass, the depth setting was altered to determine whether the effect of this setting affected the accuracy of the GPR in locating the roots. Although it was not expected that there would be any significant effect, the experiment tested this aspect of GPR use. For the $200 \mathrm{~mm}$ trench and the $400 \mathrm{~mm}$ trench, the GPR was set to scan at three different depths. Pass one was set to scan to the maximum depth of 1000 $\mathrm{mm}$. Therefore, on the $200 \mathrm{~mm}$ deep trench, the roots should show up in the top $20 \%$ of the display. Pass two was set to scan to a maximum depth of $700 \mathrm{~mm}$, and pass three was set to scan to a depth of $500 \mathrm{~mm}$. For the $800 \mathrm{~mm}$ trench, shallower scans could not be used due to the depth of the trench, and reducing the depth of the scan would have been restrictive due to the depth of placement of roots. Therefore, pass one and two were set to 1000 $\mathrm{mm}$ and pass three was set to $900 \mathrm{~mm}$. In total, nine scans were taken across the three trenches.

The final experiment scanned the root system of a Pistacia chinensis, one of a row of trees growing in the Burnley field station, which was approxi- mately three meters tall, with a DBH of $80 \mathrm{~mm}$. The roots were scanned using linear scans on all four sides of the tree, creating a small grid (Figure 4). Scans of the root system were taken at distances of $1000 \mathrm{~mm}, 1500 \mathrm{~mm}$ and $2500 \mathrm{~mm}$ from the trunk. Twelve scans were taken around the tree, each being $5 \mathrm{~m}$ long (60 $\mathrm{m}$ in total). In this experiment, both root location and numbers were of interest as in contrast to the first two experiments, neither the number of roots nor their locations were known prior to scanning.

The lines along which the GPR scanned were then excavated to test the accuracy of the GPR. All grass was removed from around the tree using a Bobcat skid steer loader and the scanned lines were trenched using an AirSpade tool (Series 2000 150/90, Air-Spade Technology, Verona, Pennsylvania) (Figure 5) so that there was no grass present during GPR data collection. The AirSpade was coupled to a $180 \mathrm{cfm}$ Ingersoll Rand compressor which delivered air from the nozzle at mach 2 (approx. $2380 \mathrm{~km} \mathrm{hr}^{-1}$ ). The benefit of using an air excavation tool was that the soil was blasted away while leaving the roots intact (Nadyezdhina and Cermàk 2003). Following excavation, all roots over $5 \mathrm{~mm}$ in diameter, measured with calipers, were counted along each trench. The roots were put into two categories, less than $10 \mathrm{~mm}$ and greater than $10 \mathrm{~mm}$. Although root sizes of $10 \mathrm{~mm}$ diameter and above were used in the first two experiments, the smaller root size class was collected in the field experiment in case the data were needed for interpretation of the root scans. The roots that crossed each trench were counted and compared to the GPR results. Roots were counted in three squares, but not at the corners due to the possibility of overlap and double counting.

The GPR scan profiles were processed through TreeWin, a specialist software package for use with the Tree Radar designed to increase the signal to noise ratio (Guo et al. 2013). The processing includes algorithms that reduce noise, clutter, and signal amplitude losses. Following collection and visual examination of the data, scans at $200 \mathrm{~mm}$ and $400 \mathrm{~mm}$ depth were subjected to a two-tailed paired-sample t-test to assess significance difference ( $\alpha=0.05)$ between the predicted and known horizontal and vertical root locations along the trenches. At $800 \mathrm{~mm}$, the presence of a large num- 


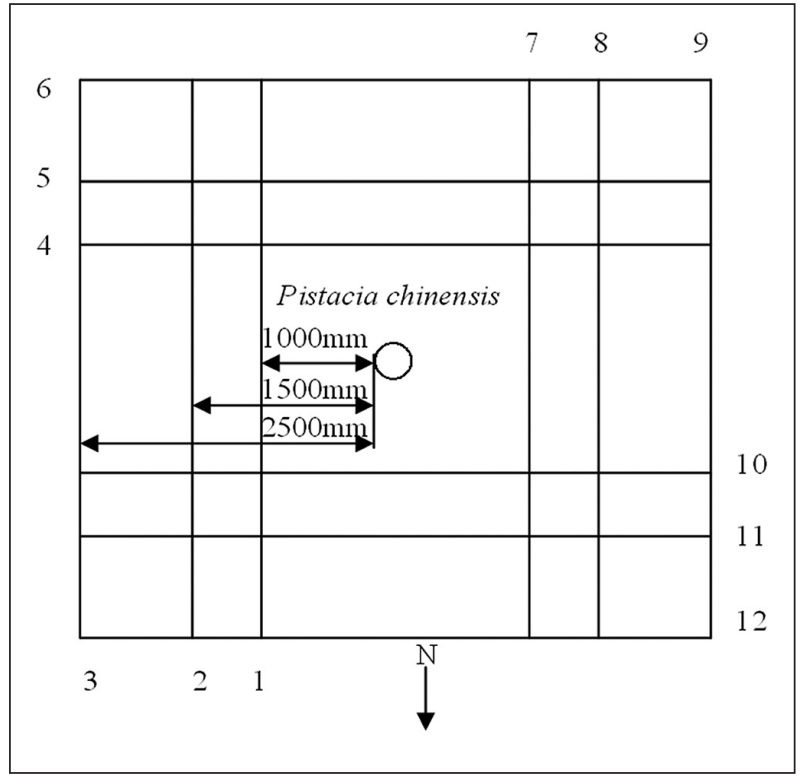

Figure 4. Schematic diagram for scanning the root system of Pistacia chinensis (Chinese pistachio) in situ for the third experiment.

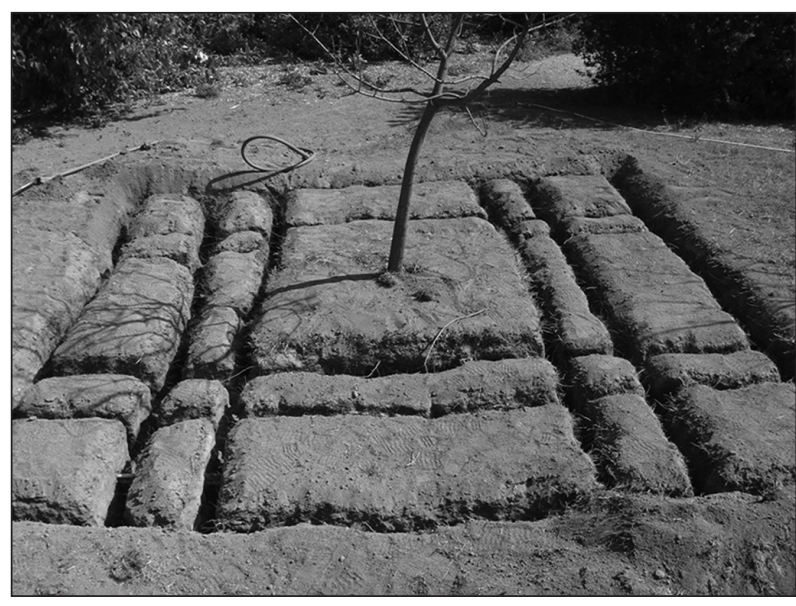

Figure 5. Trenching via air excavation tool for root counts after the scanning of the root system of Pistacia chinensis (Chinese pistachio) in situ for the third experiment.

ber of phantom data points meant that a two-tailed paired-sample t-test was no longer applicable.

The TreeWin analyses were undertaken by people who knew that roots as small as $10 \mathrm{~mm}$ and up to $50 \mathrm{~mm}$ in diameter were being used in the experiment, but they were not provided with further detail of the experimental design. Roots were identified from changes in the patterns in the radargrams, where a root appeared as an inverted parabola. The analyses were undertaken in this way to reduce the possibility of operator bias in the detection of the buried roots, their depth, and the capacity of GPR to discriminate between two closely adjacent roots.

\section{RESULTS}

At a depth of $200 \mathrm{~mm}$, the GPR device located roots well. Scans 1 and 2 showed all nine roots in close proximity to their known positions. In Scan 3 , however, a phantom root was detected resulting in a total of 10 roots (Table 1). The cause for the detection of an extra root in the one scan is unknown. The phantom root was omitted and the data subjected to the two-tailed paired-sample t-test showed that there was no significant difference from the expected positions $(P>0.05)$ in the horizontal location of the roots, meaning the GPR located them well, but there was variation in the predicted depths (Figure 6; Table 2).

At $400 \mathrm{~mm}$ depth, the level of error in accurately locating the position of roots increased, with only one scan (Scan 4) detecting nine roots, while in the other two scans, roots were either missed or phantom roots detected. With missed or phantom roots omitted there was no significant difference from the expected positions $(P>0.05)$ in the horizontal location of the roots. The predicted average depth of the roots was $278 \mathrm{~mm}$ and the horizontal

Table 1. Number of roots detected by GPR and the predicted depth of roots in each scan at depths of 200,400 , and $800 \mathrm{~mm}$.

\begin{tabular}{llll}
\hline $\begin{array}{l}\text { Depth of Roots } \\
(\mathrm{mm})\end{array}$ & $\begin{array}{l}\text { Scan } \\
\text { number }\end{array}$ & $\begin{array}{l}\text { Number of } \\
\text { roots }\end{array}$ & $\begin{array}{l}\text { Mean predicted } \\
\text { depth of roots }(\mathrm{mm})\end{array}$ \\
\hline 200 & 1 & 9 & 169 \\
& 2 & 9 & 153 \\
& 3 & 10 & 141 \\
400 & & & \\
& 4 & 9 & 298 \\
& 5 & 8 & 274 \\
800 & 6 & 10 & 263 \\
& & & \\
& 7 & 11 & 395 \\
& 8 & 11 & 308 \\
\hline
\end{tabular}

Table 2. Results for a two-tailed paired-sample t-test for roots buried $200 \mathrm{~mm}$ deep in Experiment 1.

\begin{tabular}{llllll}
\hline Scan & Axis & $\begin{array}{l}\text { Mean difference } \\
(\mathrm{mm})\end{array}$ & SE mean & T-value & $P$-value \\
\hline 1 & & & & & \\
\hline & $\mathrm{x}$ & -156.11 & 32.57 & -4.79 & 0.001 \\
2 & $\mathrm{y}$ & 8.00 & 7.93 & 1.01 & 0.343 \\
& $\mathrm{x}$ & -21.67 & 35.21 & -0.62 & 0.550 \\
& $\mathrm{y}$ & 23.22 & 5.10 & 4.55 & 0.002 \\
3 & $\mathrm{x}$ & 13.89 & 38.48 & 0.36 & 0.728 \\
& $\mathrm{y}$ & 31.22 & 3.40 & 9.19 & $<0.001$ \\
\multirow{2}{*}{ Average } & $\mathrm{x}$ & -54.63 & 33.79 & -1.62 & 0.145 \\
& $\mathrm{y}$ & 20.81 & 5.03 & 4.13 & 0.003 \\
\hline
\end{tabular}




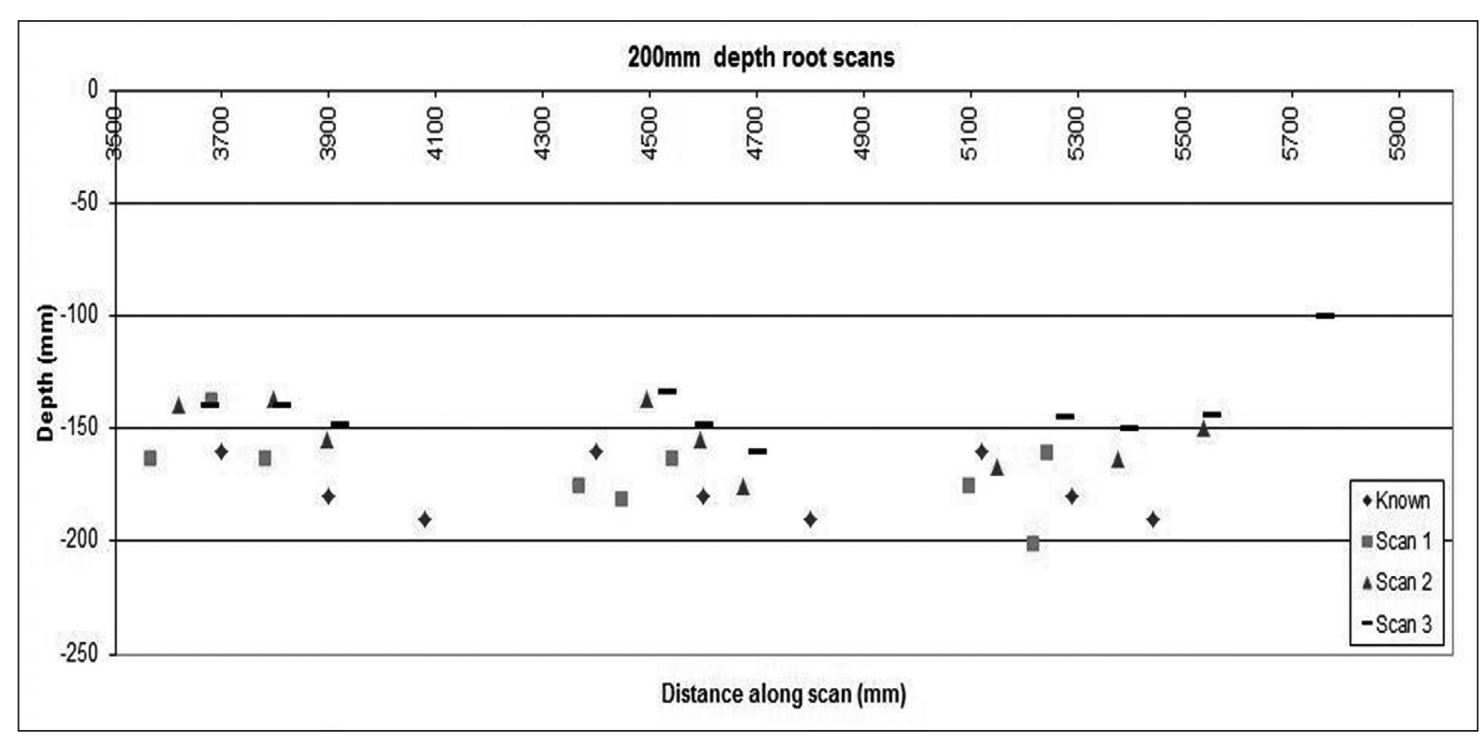

Figure 6. Scanning results for Experiment 1 for all three scans at $200 \mathrm{~mm}$ depth.

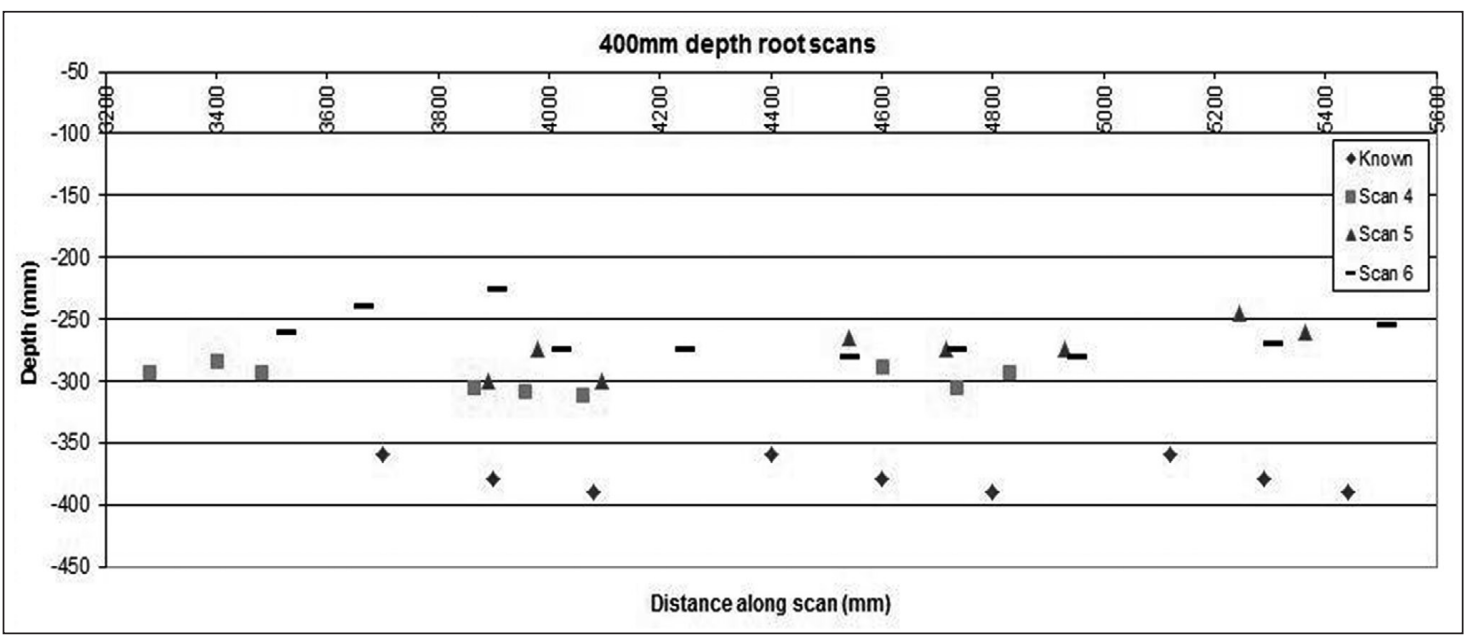

Figure 7. Scanning results for Experiment 1 for all three scans at $400 \mathrm{~mm}$ depth.

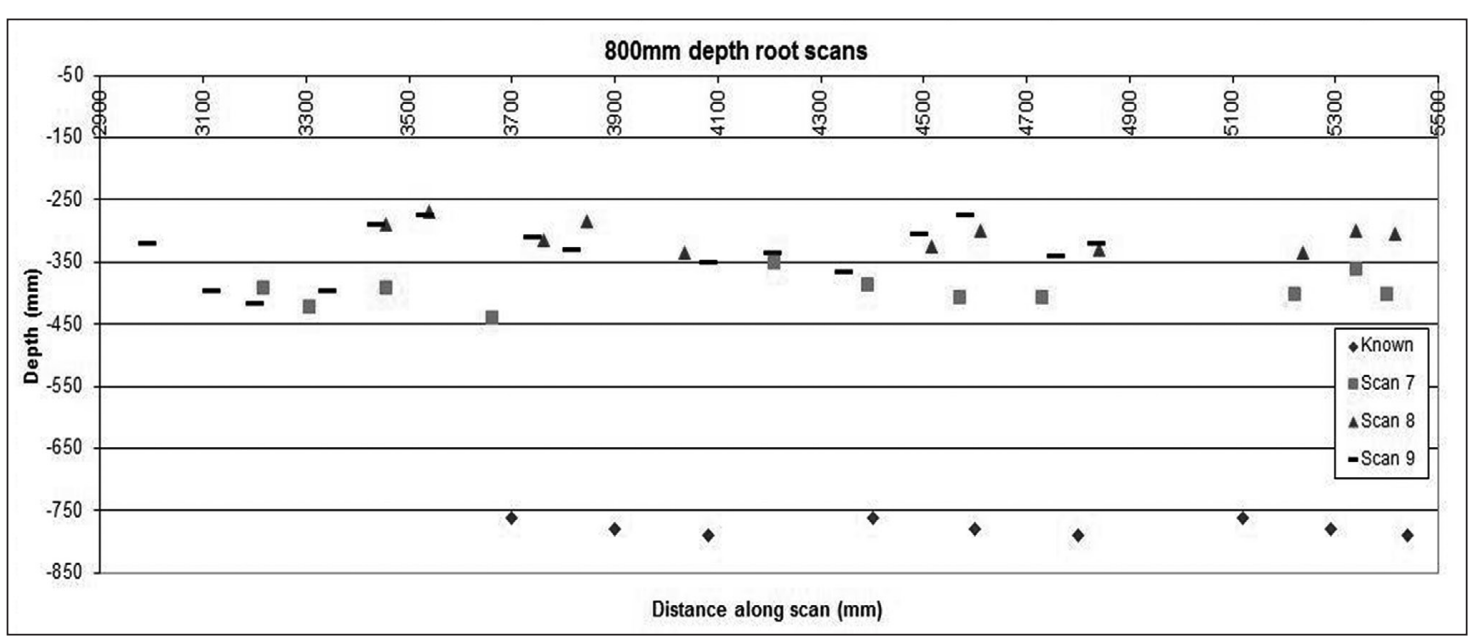

Figure 8. Scanning results for Experiment 1 for all three scans at $800 \mathrm{~mm}$ depth. 


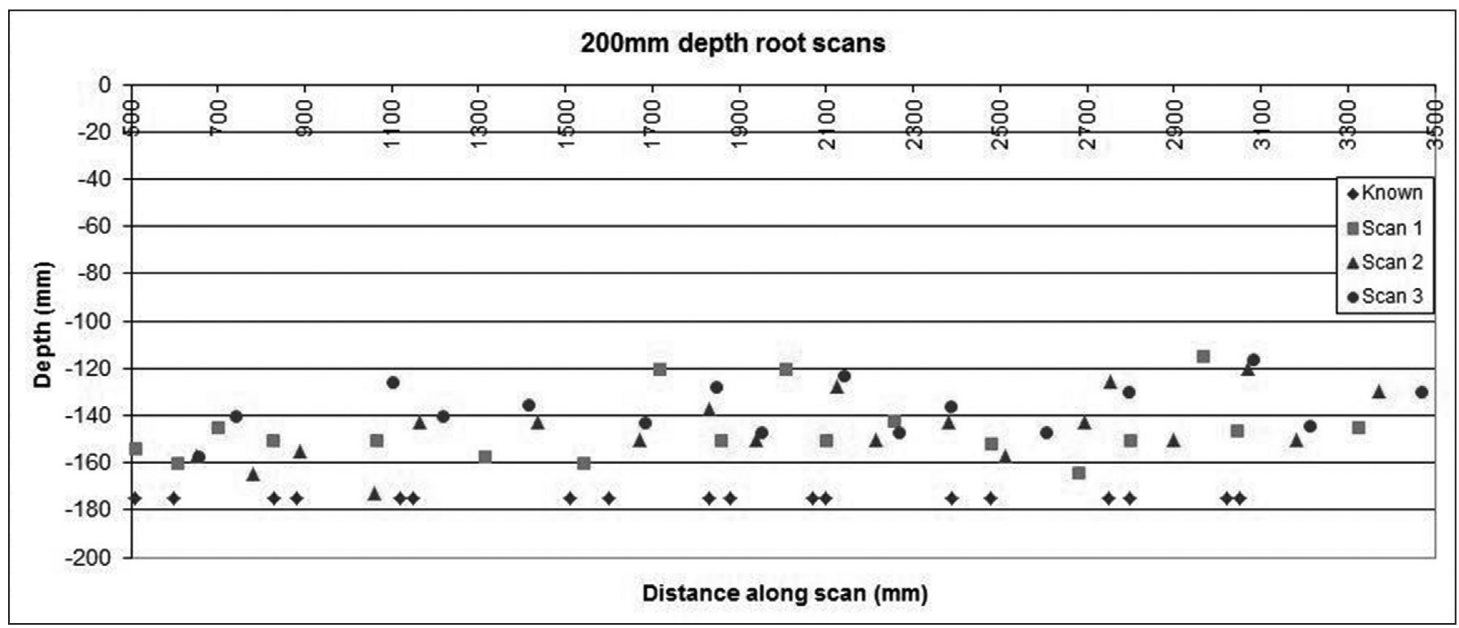

Figure 9. Scanning results for Experiment 2 for all three scans at $200 \mathrm{~mm}$ depth.

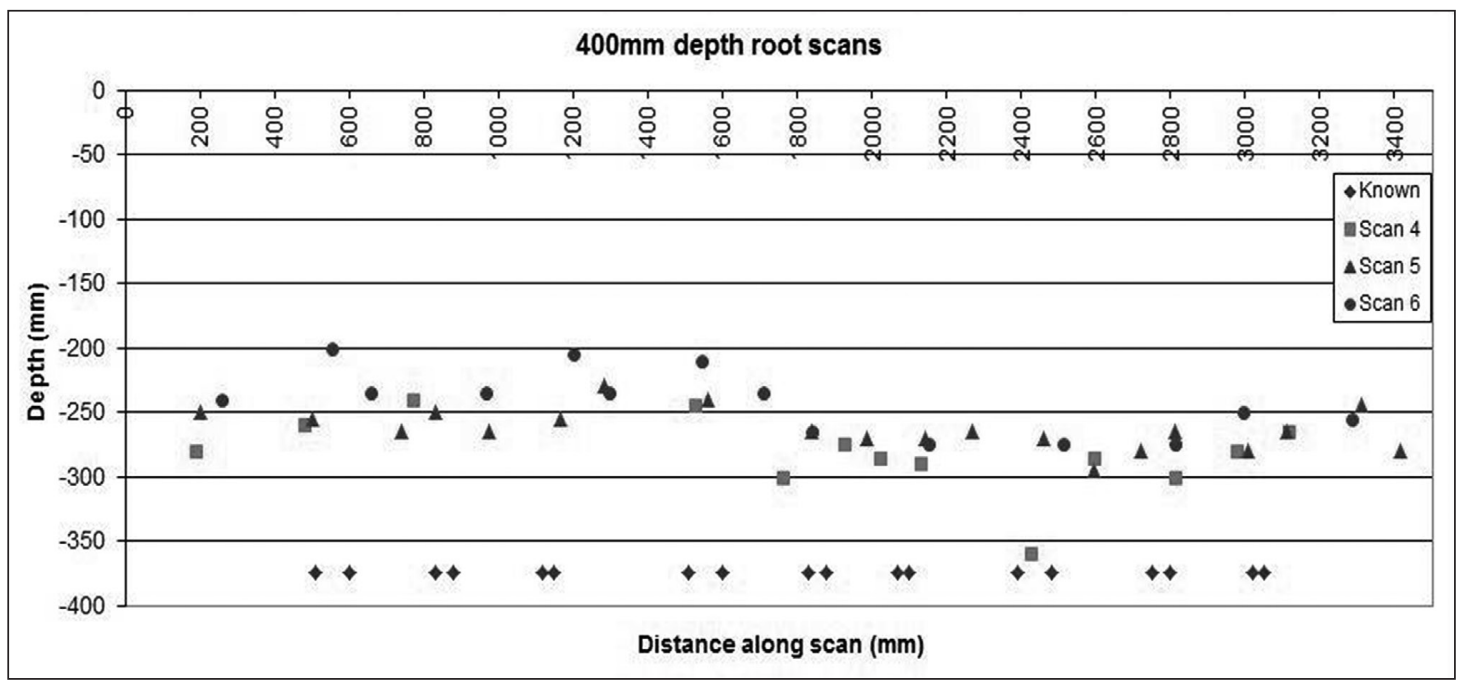

Figure 10. Scanning results for Experiment 2 for all three scans at $400 \mathrm{~mm}$ depth.

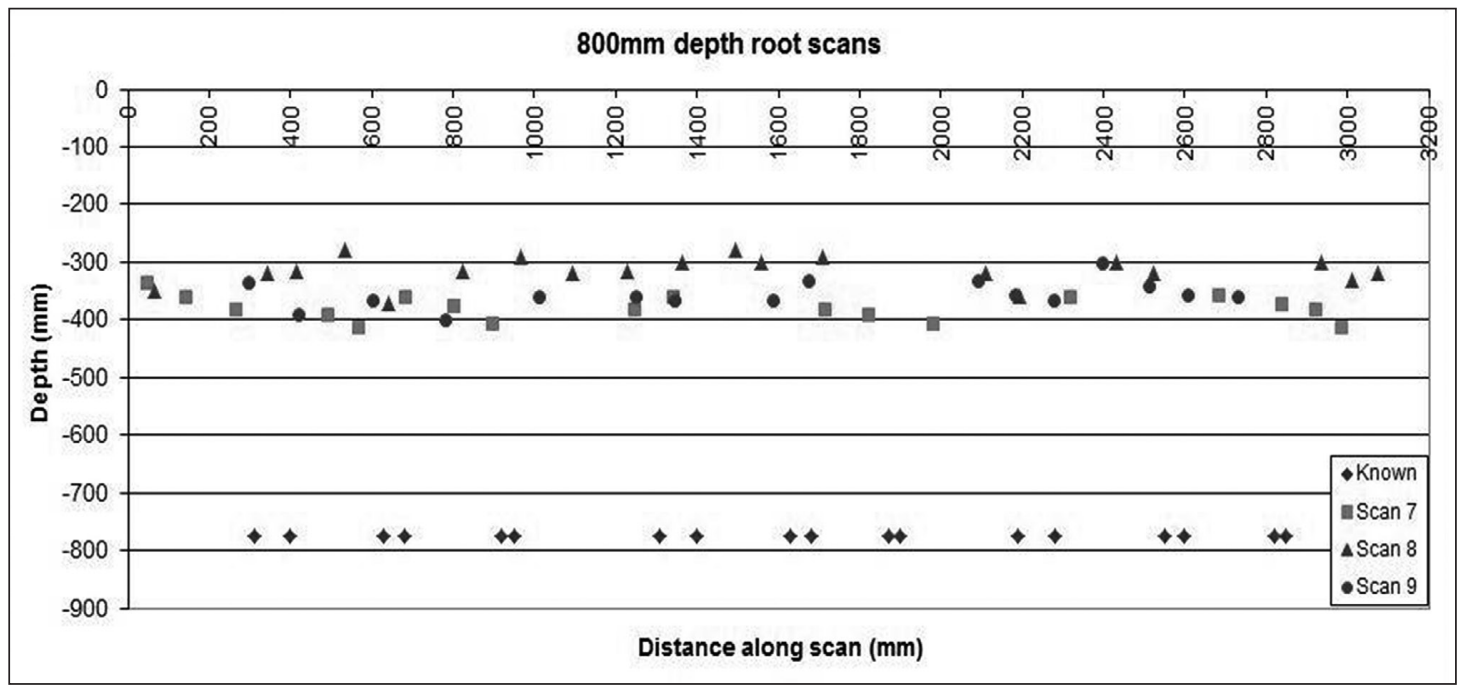

Figure 11. Scanning results for Experiment 2 for all three scans at $800 \mathrm{~mm}$ depth. 
variability was significantly greater (Figure 7). Similarly, at $800 \mathrm{~mm}$ depth, the GPR device detected more than just the nine roots in every scan, to a maximum of 15 roots (Figure 8 ). The three replicates of the three different roots sizes were not detected; the maximum predicted depth was 440 $\mathrm{mm}$, and the average was $345 \mathrm{~mm}$, approximately half the depth at which the roots were buried.

For the second experiment, aimed at locating paired roots (Table 3), at $200 \mathrm{~mm}$ depth, GPR clearly detected the tree roots, and the estimate of the depth of the roots was also accurate (Figure 9). While differences in the number of predicted roots compared to the buried sample were significant, GPR generally detected roots where they had been buried despite these errors.

At $400 \mathrm{~mm}$ depth, the GPR detected roots, however, none of the scans detected 18 roots (Figure 10). A loss of accuracy occurred, both in detection and estimates of depth, and there was considerable variability with regard to the location, but almost all root location points were within $50 \mathrm{~mm}$ of the mean recorded depth. At $800 \mathrm{~mm}$ depth, the average detection of root depth was significantly different from the real depth $(P<0.05)$, with all scans estimating roots to be located at a depth of approximately $400 \mathrm{~mm}$ - half that of the actual depth (Figure 11). Only one scan (Scan 7) detected 18 roots, while Scans 8 and 9 predicted 20 and 16 roots, respectively. The GPR device did detect roots but estimated the depth of roots at a range of between 300-400 $\mathrm{mm}$, or approximately half the true depth.

The experiment that investigated the root system of the Pistacia chinensis in situ was done by counting the roots observed in each trench (Table 4). This experiment was conducted in a typical arboricultural field situation with an uncontrolled environment and disturbed urban soils. There were large differences

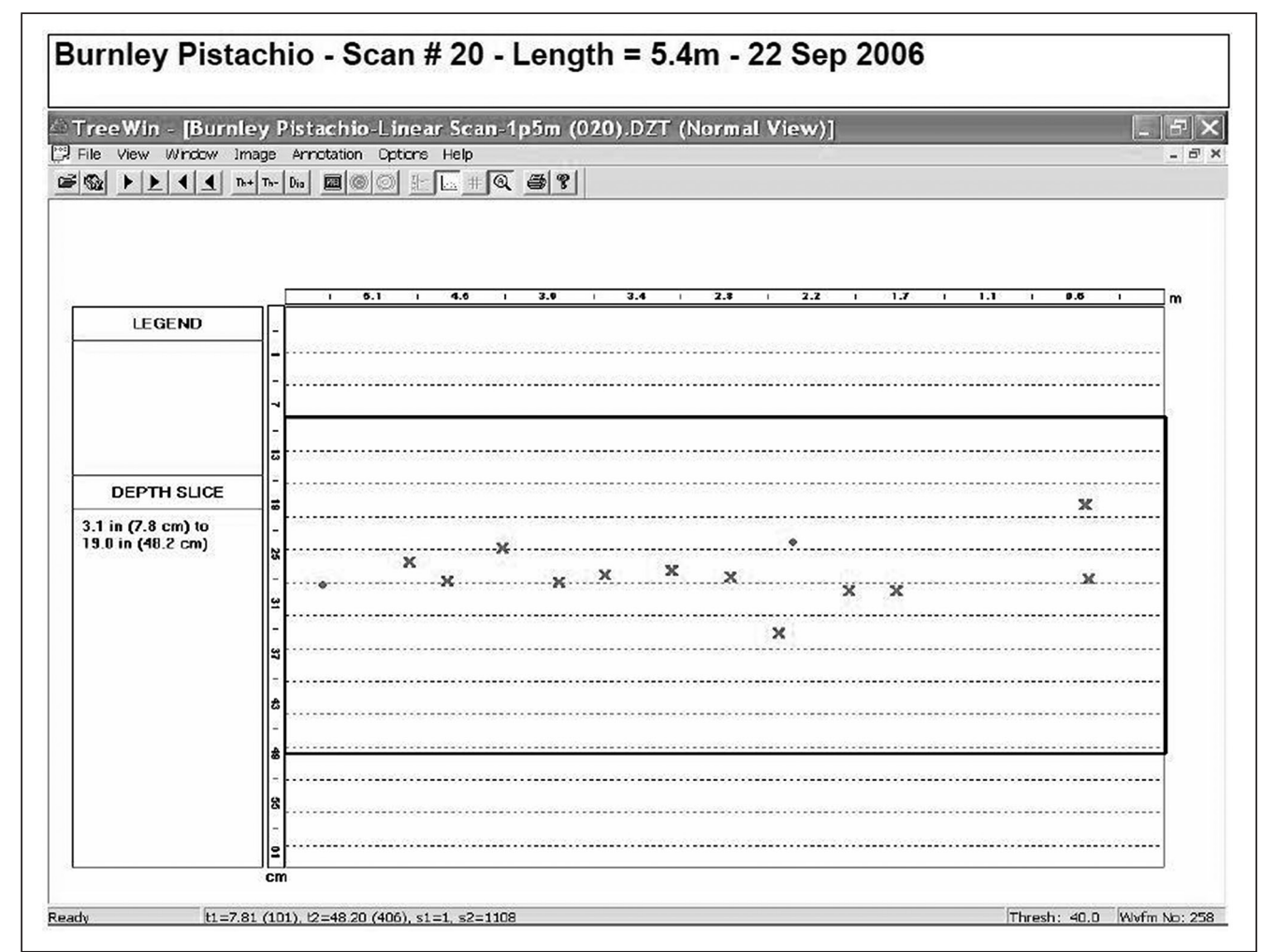

Figure 12. A sample scan for one of the 12 scans conducted on the root system of Pistacia chinensis (Chinese pistachio) in situ for the third experiment. The $\mathrm{x}$ represents roots and the square symbols represent other harder objects, such as stones or utility pipes. 


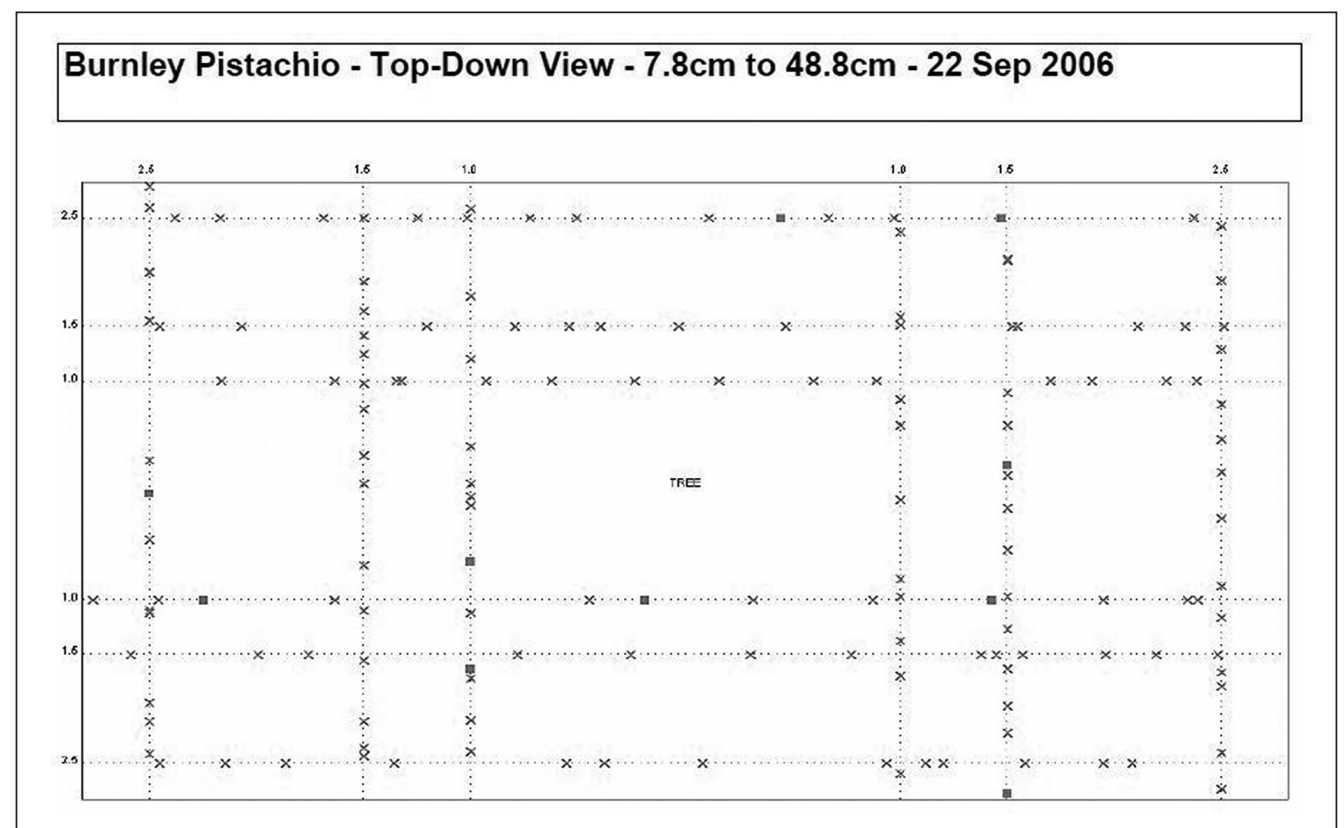

Figure 13. A top-down view of the 12 scans conducted on the root system of Pistacia chinensis (Chinese pistachio) in situ for the third experiment and the predicted root locations. The $\mathrm{x}$ represents roots and the square symbols represent other harder objects, such as stones or utility pipes.

Table 3. Number of roots detected by GPR and the predicted depth of roots for the paired root detection experiment for each scan at depths of 200,400 , and $800 \mathrm{~mm}$.

\begin{tabular}{lllll}
\hline $\begin{array}{l}\text { Depth of } \\
\text { roots }(\mathrm{mm})\end{array}$ & Scan number & $\begin{array}{l}\text { Mean depth } \\
(\mathrm{mm})\end{array}$ & $\begin{array}{l}\text { Range } \\
(\mathrm{mm})\end{array}$ & $\begin{array}{l}\text { Number } \\
\text { detected }\end{array}$ \\
\hline 200 & 1 & 146 & $(164,115)$ & 18 \\
& 2 & 145 & $(173,120)$ & 19 \\
& 3 & 136 & $(157,116)$ & 16 \\
& Total & -143 & $(115,173)$ & - \\
400 & & & & \\
& 4 & -282 & $(-360,-240)$ & 13 \\
& 5 & -263 & $(-295,-230)$ & 20 \\
& 6 & -242 & $(-275,-200)$ & 14 \\
& Total & -262 & $(-360,-200)$ & - \\
800 & 7 & & & \\
& 7 & -378 & $(-410,-335)$ & 18 \\
& 8 & -315 & $(-370,-280)$ & 20 \\
& 9 & -355 & $(-400,-300)$ & 16 \\
& Total & -348 & $(-410,-280)$ & - \\
\hline
\end{tabular}

between the number of roots that the GPR predicted and the number of roots counted, especially in the trenches $2.5 \mathrm{~m}$ from the trunk (Table 5 ), where 52 roots were predicted by the GPR but only one root was counted. Consequently, there were significant differences $(P$ $<0.05$ ) between the observed and predicted roots numbers. A sample of the 12 scans conducted for this experiment is provided in Figure 12, and a summary of the locations of all predicted roots is presented in Figure 13.

\section{DISCUSSION}

Statistical analysis showed that at $200 \mathrm{~mm}$ depth, the vertical location of roots was more accurately depicted by the GPR scans than the horizontal location with two out of three scans and the overall average at $200 \mathrm{~mm}$ depth was not significantly different from the known root locations, which is consistent with other studies (Guo et al. 2013). Predicted root locations (Figure 6; Figure 9) and the true root locations were in close proximity, with roots located within $130-200 \mathrm{~mm}$ of their actual location. For $200 \mathrm{~mm}$ depth, scans provide valuable information about root position for arborists. Nadyezdhina and Cermàk (2003) noted an error margin using GPR of about $50 \mathrm{~mm}$, with a detection rate of approximately $80 \%$. The average horizontal and vertical error across the three scans was $54 \mathrm{~mm}$ and $21 \mathrm{~mm}$, respectively, showing that the depth reading was more accurate than root location along the scan line, probably because it was difficult to follow exactly the same transect line in successive passes. All roots were identified at $200 \mathrm{~mm}$ depth.

As the depth of inspection increased to 400 $\mathrm{mm}$, so did the level of error in accurately locating the roots (Figure 7; Figure 10). However, for most arboricultural field situations, this level of accuracy would be both acceptable and useful. Similar 
Table 4. Summary counts for predicted and observed root numbers for each excavated trench of the root system of Pistacia chinensis (Chinese pistachio) in situ for the third experiment.

\begin{tabular}{|c|c|c|c|c|c|}
\hline & \multirow{2}{*}{$\begin{array}{l}\text { Distance of trench } \\
\text { from trunk }(\mathrm{m})\end{array}$} & \multirow{2}{*}{$\begin{array}{l}\text { Tree Radar } \\
\text { predicted roots }\end{array}$} & \multicolumn{3}{|c|}{ Excavated observed roots } \\
\hline & & & $<10 \mathrm{~mm}$ & $>10 \mathrm{~mm}$ & Total roots \\
\hline \multirow[t]{3}{*}{ Side 1} & 1 & 4 & 10 & 2 & 12 \\
\hline & 1.5 & 4 & 8 & 0 & 8 \\
\hline & 2.5 & 13 & 1 & 0 & 1 \\
\hline \multirow[t]{3}{*}{ Side 2} & 1 & 6 & 7 & 1 & 8 \\
\hline & 1.5 & 8 & 10 & 0 & 10 \\
\hline & 2.5 & 13 & 0 & 0 & 0 \\
\hline \multirow[t]{3}{*}{ Side 3} & 1 & 5 & 14 & 2 & 16 \\
\hline & 1.5 & 8 & 5 & 1 & 6 \\
\hline & 2.5 & 13 & 0 & 0 & 0 \\
\hline \multirow[t]{3}{*}{ Side 4} & 1 & 5 & 2 & 0 & 2 \\
\hline & 1.5 & 9 & 1 & 0 & 1 \\
\hline & 2.5 & 13 & 0 & 0 & 0 \\
\hline Total & & 101 & 58 & 6 & 64 \\
\hline
\end{tabular}

Table 5. Summary counts for predicted and observed root numbers for each excavated trench at $1 \mathrm{~m}, 1.5 \mathrm{~m}$, and $2 \mathrm{~m}$ from the tree trunk of the root system of Pistacia chinensis (Chinese pistachio) in situ for the third experiment showing the major difference between predicted and observed root counts was for the $2.5 \mathrm{~m}$ trench.

\begin{tabular}{lllll}
\hline & \multicolumn{3}{c}{ Observed roots } & \multirow{2}{*}{$\begin{array}{c}\text { Tree Radar } \\
\text { prediction }\end{array}$} \\
\cline { 2 - 4 } & $<10 \mathrm{~mm}$ & $>10 \mathrm{~mm}$ & Total & pred \\
\hline 1 m square & 33 & 5 & 38 & 20 \\
1.5 m square & 24 & 1 & 25 & 29 \\
2.5 m square & 1 & 0 & 1 & 52 \\
Total & 58 & 6 & 64 & 101 \\
\hline
\end{tabular}

results were found when scanning roots at different depths (Butnor et al. 2001). The detection of phantom roots could be due to high levels of noise interference or clutter, to which GPR is vulnerable at short range often due to rough ground surfaces (Daniels 1996; Daniels 2004). In tests of GPR performance using sandboxes with buried items, additional signal traces appeared due to the sides of the box (Wielopolski et al. 2000). The sides of the trench could have a higher bulk density than the fill soil, creating reflections that were misinterpreted as roots. Orientation of the antennas was not considered as part of these experiments, but a change in orientation from parallel to perpendicular can significantly reduce interference (van der Kruk and Slob 2004). In both experiments, the orientation of the antenna was held constant and the radar transects were perpendicular to the roots thereby optimizing detection capacity.

With an average of three phantom roots detected in each scan at $800 \mathrm{~mm}$ depth, the true roots could not be separated from phantom roots (Figure 8; Figure 11). The average recorded depth was 345 $\mathrm{mm}$. Depth is calculated by using the propagation velocity according to the following equation:

$$
\text { [1] } \quad \mathrm{D}=\mathrm{V} \times(\mathrm{T} / 2)
$$

where $\mathrm{D}=$ depth, $\mathrm{V}=$ velocity of propagation, and $\mathrm{T}=$ two-way travel time.

The GPR was set for 'standard soil' for these experiments, which approximates a propagation velocity of $9 \mathrm{~cm} / \mathrm{nsec}$, which may be an underestimate of real velocity under these conditions. Daniels (1996) explains it is not possible to make reliable estimates of propagation velocity or relative permittivity in a medium from a single measurement without trial holing and calibration against buried metallic discs. However, this detailed calibration is not routinely done for soils, which the operator of the GPR device considers to be appropriate for the 'standard soil' setting.

As depth of root burial increased, the errors in depth estimates increased. This may have been because the GPR was calibrated using the Autocal function only at the beginning of Scan 1. This function, which corrects gain and phase estimation errors, is not as accurate as calibrating the GPR for a particular soil prior to scanning. Conyers and Cameron (1998) found that inaccurate calibration led to poor results, and in other studies of root systems being mapped and depth determined, discs were buried to manually calibrate the GPR (Butnor et al. 2001; Stokes et al. 2002; Butnor et al. 2003). 
In other instances, relative distance and depth have been considered to be sufficient, and so absolute depth was not determined (Hruška et al. 1999), which is more likely to be the practice for arborists using GPR in the field. In many field situations, arborists would be concerned more with root detection, rather than the accuracy of depth predictions and so would be prepared to trade ease and speed of operation against the accuracy of depth.

The misdetection of roots was most likely due to poor resolution and confusing wavelets that showed up on the scan. If the object of investigation is smaller than the wavelength, then it can be easily missed (Wielopolski et al. 2000; Gibson and George 2004). Transmission and retransmission losses are unlikely as the GPR device was rolled across the ground at no more than $10 \mathrm{~mm}$ from its surface (Daniels 1996). This particular GPR model was able to determine the location of coarse tree roots with diameters down to $10 \mathrm{~mm}$ at shallow depths, but at greater depths there were increasing errors, both in the spatial position horizontally and vertically, as well as the misdetection of roots and the creation of phantom roots.

In the scans for the experiment on paired roots, GPR detected the presence of roots, but even at $200 \mathrm{~mm}$ depth, the signal did not always reveal the presence of two roots (Figure 9). Butnor et al. (2001) found that there can be signal conflict when there are multiple roots present, as one can mask another or change the shape of the hyperbola. Evidence of replicates was missing in all of the scans even though there was a $300 \mathrm{~mm}$ gap between replicates, which should have allowed for discrimination. The optimum resolution for the GPR, using a $900 \mathrm{MHz}$ antenna set to 'standard soil', according to manufacturer's specifications, is $26 \mathrm{~mm}$, which is in good agreement with Conyers and Cameron (1998). The device should have been suitable for detecting buried roots of between 10-15 mm diameters, and so the choices of using roots $20-30 \mathrm{~mm}$ in diameter at gaps of $20 \mathrm{~mm}, 40 \mathrm{~mm}$, and $80 \mathrm{~mm}$ were across the published range for the instrument. It is likely that this margin of error would be acceptable to practicing arborists trying to locate tree roots.

The experiment on Pistacia chinensis in situ was conducted to test GPR under field conditions where soils were uncontrolled and less than ideal for GPR use. The soil around these roots was not unconsolidated fill, like that used to bury the roots in trenches, and there was no risk of root desiccation. Dead and decaying roots were undetectable in forest GPR studies (Butnor et al. 2001), and readings changed as sand placed in pits was allowed to settle over a four-week period (Barton and Montagu 2004). Bassuk et al. (2011) found an increase in the number of misdetected roots in compacted soil compared to CU-Structural Soil ${ }^{\text {Tit }}$.

Misdetection of roots could result from signal loss, antenna spreading loss-involving the inverse fourth power of distance for a point reflector (the root) (Daniels 1996) as it gets deeper (farther away) the signal will spread more and be more wide-ranging with a much weaker signal returning to the receiver-or attenuation and scattering losses occurring as the wave moves through the medium (Daniels 1996). Misdetection of roots is most likely due to poor resolution and confusing wavelets showing up on the scan. Unless scanning occurs under optimal conditions, if the object of investigation is smaller than the wavelength, then it can be easily missed (Wielopolski et al. 2000; Gibson and Geirge 2004). However, transmission and retransmission loss are unlikely as the GPR device was rolled across the ground at no more than $10 \mathrm{~mm}$ from its surface (Daniels 1996).

The detection of phantom roots, particularly in the outer trench, suggests that the GPR was either detecting other subsurface features (e.g., stones, wood, utility pipes), or there was interference from aboveground objects resulting in false root detection. There were only three roots to be found in total on Side 4 (Table 4), which was next to a vehicle path that over the years has become compacted. Highly compacted soils present a physical barrier to root growth (Craul 1992), and it is not surprising for there to be few roots in this area as root growth is generally opportunistic and follows the path of least resistance (Perry 1982). Trees growing near roads have been found to have asymmetric root systems (Cermák et al. 2000).

The differences between the predicted and the observed number of roots, particularly in the 2.5 $\mathrm{m}$ trenches, would suggest that the post-processing algorithms and filters were insufficient to remove noise, clutter, and unwanted objects. During the AirSpade excavation, some debris (stones and wood) were identified but too few to account for the prediction of 52 roots. Conversely, in the one meter trench, 
many more roots were observed than were predicted, probably because multiple small roots $(<10 \mathrm{~mm})$ showed as one root (Butnor 2001; Butnor 2003).

The GPR instrument used in this research operated with a $900 \mathrm{MHz}$ antenna with $100 \%$ bandwidth, which allowed scanning within the frequency range $450-1350 \mathrm{MHz}$ with a claimed minimum detectable root diameter of $10-15 \mathrm{~mm}$. Although this should have been sufficient to define the roots that were buried, the use of a higher frequency antenna would have been beneficial and the device can be coupled to a $1500 \mathrm{MHz}$ antenna that would resolve smaller roots but only to depths of $500 \mathrm{~mm}$. Wielopolski et al. (2000) used a 1500 $\mathrm{MHz}$ antenna to a depth of $700 \mathrm{~mm}$ and under optimum conditions resolved a $2.5 \mathrm{~mm}$ twig.

The GPR was not recalibrated using the Autocal function every time the depth settings were changed. Parameters such as operating frequency, gain, bandwidth, relative permittivity, resolution, depth, antenna choice, and sampling intervals all interact with each other and are important in determining the best setup for the desired application (Daniels 2004; Gibson and George 2004). It might be wise operating procedure to recalibrate the machine before each pass, but this has to be balanced against the time constraints that apply in the field arboriculture application. If soil conditions are relatively consistent, re-calibration after each pass is unnecessary as long as one calibration for signal velocity has been made.

GPR is complex technology with wide-ranging application and its use in arboriculture is relatively novel. The instrument used in this research is among the first generation of instruments with signal processing designed for root scanning use; future improvements can be expected as operators become better trained and experienced in its use for different species growing in different soil types and under varying landscape conditions (Wu et al. 2014). The ramifications of missing roots could result in an underestimation of the extent of the structural roots of a tree, which could see a sound and safe tree removed unnecessarily, while the reverse could apply for false positives.

GPR accurately detected larger roots and particularly those at depths of less than $400 \mathrm{~mm}$ under difficult field conditions. Under these challenging and uncontrolled conditions, where there is the potential for signal interference from disturbed soils and from the sides of trenches, the GPR accurately located roots of $10 \mathrm{~mm}, 20 \mathrm{~mm}$, and $40-50 \mathrm{~mm}$ diameter to a depth of at least $400 \mathrm{~mm}$. This would be sufficient for many urban soils where soil disturbance during development leads to shallow spreading root systems. Development of an effective method of noninvasively mapping tree roots provides a significant advance in the management of tree roots systems and their interaction with urban infrastructure.

Acknowledgments. This research was part of a Bachelor of Applied Science Horticulture (Honours) project undertaken by C.M. Ryder at the University of Melbourne, Burnley Campus. Use of the field station and the support of technical staff is gratefully acknowledged. Mr. R. Knott, R\&T Tree Services is thanked for allowing the use of the Tree Radar instrument, as is Mr. D. Gunter, arborist with R\&T Tree Services for help in operating the Tree Radar and providing the technical support. Dr. A. Mucciardi, president, Tree Radar Inc. is thanked for allowing the independent testing of Tree Radar in Australia and giving technical advice on GPR. Mr. D. Hammersley provided labor in adverse conditions. Dr. Peter Ades, Melbourne School of Land and Environment, The University of Melbourne, is thanked for assisting in data analysis. Ms. E. Moore, linguist, and Ms. R. Ryder are thanked for their critical reading of the manuscript and their helpful suggestions.

\section{LITERATURE CITED}

Akinnifesi, F.K., B.T. Kang, and D.O. Ladipo. 1999. Structural root form and fine root distribution of some woody species evaluated for agroforestry systems. Agroforestry Systems 42:121-138.

Barton, C.V.M., and K.D. Montagu. 2004. Detection of tree roots and determination of root diameters by ground-penetrating radar under optimal conditions. Tree Physiology 24:1323-1331.

Bassuk, N., J. Grabosky, A. Mucciardi, and G Raffel. 2011. Groundpenetrating radar accurately locates tree roots in two soil media under pavement. Journal of Arboriculture 37:160-166.

Butnor, J.R., J.A. Doolittle, K.H. Johnsen, L. Samuelson, T. Stokes, and L. Kress. 2003. Utility of ground-penetrating radar as a root biomass survey tool in forest systems. Soil Science Society of America Journal 67:1607-1615.

Butnor, J.R., J.A. Doolittle, L. Kress, S. Cohen, and K.H. Johnsen. 2001. Use of ground-penetrating radar to study tree roots in the southeastern United States. Tree Physiology 21:1269-1278.

Bureau of Meteorology. 2013. Daily Temperature and Rainfall Data, Melbourne Airport, 1971-2013. Australian Government.

Cermák, J., J. Hruška, M. Martinková, and A. Prax. 2000. Urban tree root systems and their survival near houses analyzed using ground-penetrating radar and sap flow techniques. Plant and Soil 219:103-116.

Coder, K.D. 1998. Root growth control: Managing perceptions and realities, pp. 51-81. In: D. Neely and G.W. Watson (Eds.). The Landscape Below Ground II, paper presented to Second International Workshop on Tree Root Development in Urban Soils. International Society of Arboriculture, Champaign, Illinois, U.S.

Conyers, L.B., and C.M. Cameron. 1998. Ground-penetrating radar techniques and three-dimensional computer mapping in the American southwest. Journal of Field Archaeology 25:417-430. 
Craul, P.J. 1992. Urban Soil in Landscape Design. John Wiley and Sons Inc., New York, U.S.

Cui, X., L. Guo, X. Chen, J. Chen, and X. Zhu. 2013. Estimating tree-root biomass in different depths using ground-penetrating radar: Evidence from a controlled experiment. IEEE Transactions on Geoscience and Remote Sensing 51:3410-3423.

Cutler, D.F. 1995. Interactions between tree roots and buildings, pp. 78-87. In: G.W. Watson and D. Neely (Eds.). Trees and Building Sites, Paper presented to Proceedings of an International Workshop on Trees and Buildings. International Society of Arboriculture, Champaign, Illinois, U.S.

Daniels, D.J. 1996. Surface Penetrating Radar, The Institution of Electrical Engineers, London, UK.

Daniels, D.J. 2004. Ground-Penetrating Radar, second edition. The Institute of Electrical Engineers, UK.

Gibson, P.J., and D.M. George. 2004. Environmental Applications of Geophysical Survey Techniques. Nova Science Publishers Inc., New York, U.S.

Guo, L., J. Chen, X. Cui, B. Fan, and H. Lin. 2013. Application of ground-penetrating radar for coarse root detection and quantification: A review. Plant Soil 362:1-23.

Harris, R.W., J.R. Clark, and N.P. Matheny. 1999. Arboriculture. Integrated Management of Landscape Trees, Shrubs, and Vines, third edition. Prentice Hall.

Havis, L. 1938. Peach tree root distribution. Ecology 19:454-462.

Hirano, Y., R. Yamamoto, M. Dannoura, K. Aono, T. Igarashi, M, Ishii, K. Yamase, N. Makita, Y. Kanazawa. 2012. Detection frequency of Pinus thunbergii roots by ground-penetrating radar is related to root biomass. Plant and Soil 360:363-373.

Hitchmough, J.D. 1994. The management of trees in the urban landscape, pp. 267-300. In: Urban Landscape Management. J.D. Hitchmough (Ed.). Inkata Press, UK.

Hruška, J., J. Cermák, and S. Sustek. 1999. Mapping tree root systems with ground-penetrating radar. Tree Physiology 19:125-130.

Isaac M.E., and L.C.N. Anglaaere. 2013. An in situ approach to detect tree root ecology: Linking ground-penetrating radar imaging to isotope-derived water acquisition zones. Ecology and Evolution 3:1330-1339.

Kozlowski, T.T. 1971. Physiological ecology. Growth and development of trees. Vol. II. Academic Press, New York, U.S.

Lawson, M., and D. O'Callaghan. 1995. A critical analysis of the role of trees in damage to low rise buildings. Journal of Arboriculture 21:90-96.

Melhuish, F.M. 1968. A precise technique for measurement of roots and root distribution in soils. Annals of Botany 32:15-22.

Nadyezdhina, N., and J. Cermàk. 2003. Instrumental methods for studies of structure and function of root systems of large trees. Journal of Experimental Botany 54:1511-1521.

Perry, T.O. 1982. The ecology of tree roots and the practical significance thereof. Journal of Arboriculture 8:197-211.

Peter, I., and J. Lehmann. 2000. Pruning effects on root distribution and nutrient dynamics in an acacia hedgerow planting in northern Kenya. Agroforestry Systems 50:59-75.

Pirone, P.P., J.R. Hartman, M. Sall, and T.P. Pirone. 1988. Tree Maintenance, sixth edition. Oxford University Press, U.S.

Schnelle, M.A., J.R. Feucht, and J.E. Klett. 1989. Root systems of trees-facts and fallacies. Journal of Arboriculture 15:201-204
Shigo, A. 1991. Modern Arboriculture. A Systems Approach to the Care of Trees and Their Associates. Shigo and Trees, Associates, New Hampshire, U.S.

Ståhl, Ö., and K. Rolf. 1998. Tree roots and infrastructure, pp. 125130. In: D. Neely and G.W. Watson (Eds.). The Landscape Below Ground II, paper presented to Second International Workshop on Tree Root Development in Urban Soils. International Society of Arboriculture, Champaign, Illinois, U.S.

Stokes, A., T. Fourcaud, J. Hruška, J. Cermák, N. Nadyezdhina, V. Nadyezhdin, and L. Praus. 2002. An evaluation of different methods to investigate root system architecture of urban trees in situ: 1. Ground-penetrating radar. Journal of Arboriculture 28:2-9.

Sydnor, T.D., D. Gamstetter, J. Nichols, B. Bishop, J. Favorite, C. Blazer, and L. Turpin. 2000. Trees are not the root of sidewalk problems. Journal of Arboriculture 26:20-26.

van Dam, R.L., B. Borchers, and J.M.H. Hendrickx. 2005. Methods for prediction of soil dielectric properties: A review. In Detection and Remediation Technologies for mines and minelike targets. SPIE Proceedings 5794:188-197.

van der Kruk, J., and E.C. Slob. 2004. Reduction of reflections from above surface objects in GPR data. Journal of Applied Geophysics 55:271-278.

Watson, G.W. 1995. Tree root damage from utility trenching, pp. 33-41. In: G.W. Watson and D. Neely (Eds.). Trees and Building Sites, paper presented to Proceedings of an International Workshop on Trees and Buildings. International Society of Arboriculture, Champaign, Illinois, U.S.

Wielopolski, L., G. Hendrey, J. Daniels, and M. McGuigan. 2000. Imaging tree root systems in situ, pp. 642-646. In: D.A. Noon, G.F. Stickley, and D. Longstaff (Eds.). Paper presented to Eighth International Conference on Ground-Penetrating Radar. SPIE, Washington D.C, U.S.

Wu, Y., L. Guo, X. Cui, J. Chen, X. Cao, H. Lin. 2014. Groundpenetrating radar-based automatic reconstruction of threedimensional coarse root system architecture. Plant and Soil 383:155-172.

Zhu, J., P.A. Ingram, P.N. Benfey, and T. Elich. 2011. From lab to field, new approaches to phenotyping root system architecture. Current Opinion in Plant Biology 14:310-317.

G.M. Moore (corresponding author)

University of Melbourne, Burnley Campus

500 Yarra Boulevard

Richmond, Australia 3121

E-mail:gmmoore@unimelb.edu.au

C.M. Ryder

Senior Consulting Arborist

$C$ and R Ryder Consulting

Melbourne, Australia 
Résumé. Jusqu'à récemment, la seule manière d'examiner l'architecture des racines d'arbres et leur développement impliquait l'enlèvement physique du sol les entourant. Cependant, au cours de la dernière décennie, le radar à pénétration de sol (RPS), employé dans de multiples domaines depuis une trentaine d'années, a été utilisé afin d'étudier le système racinaire des arbres. Le RPS est relativement nouveau en Australie et l'objectif de cette recherche était d'évaluer sa précision spatiale et sa capacité à détecter les racines d'arbres.

Trois tests ont été effectués en utilisant un appareil RPS de 900 $\mathrm{MHz}$ (Tree Radar ${ }^{\circledR}$ ). Le premier test a vérifié la capacité du RPS à détecter des racines dont le diamètre était de $10 \mathrm{~mm}, 20 \mathrm{~mm}$ et 40 $\mathrm{mm}$ jusqu'à une profondeur de $200 \mathrm{~mm}, 400 \mathrm{~mm}$ et $800 \mathrm{~mm}$, tandis que le deuxième test a permis de valider la capacité de l'appareil à départager ou discerner deux racines croissant à proximité immédiate l'une de l'autre. Des racines de 20 à $30 \mathrm{~mm}$ de diamètre furent positionnées en paires à $20 \mathrm{~mm}, 40 \mathrm{~mm}$ et $80 \mathrm{~mm}$ d'écart l'une de l'autre et à des profondeurs de $200 \mathrm{~mm}, 400 \mathrm{~mm}$ et $800 \mathrm{~mm}$. Le dernier test RPS a été utilisé pour analyser le système racinaire in situ d'un petit pistachier de Chine (Pistacia chinensis) à la suite de quoi, ledit système racinaire a été dégagé en utilisant un AirSpade ${ }^{\circ}$ et le dénombrement du nombre de racines a été effectué puis comparé aux résultats obtenus avec le radar.

Le RPS a détecté et discerné avec précision des racines d'arbre à $200 \mathrm{~mm}$ de profondeur, mais à mesure que la profondeur augmentait à $400 \mathrm{~mm}$ puis à $800 \mathrm{~mm}$, les niveaux d'erreur ont augmenté, probablement en raison du choix d'antenne disponible pour les tests menant au signalement de racines fantômes dans certains résultats et à la mauvaise détection de véritables racines dans d'autres. La confusion du signal avec des interférences imprévues ou le mauvais traitement du signal par l'appareil sont vraisemblablement en cause. Lors du dernier test, le RPS n'a pas détecté de nombreuses petites racines dans les tranchées à proximité de l'arbre et a signalé plusieurs racines comme n'en constituant qu'une seule. Dans les tranchées périphériques, le RPS a discerné un total de 52 racines, mais l'excavation nen a révélé qu'une seule dans ces sols urbains perturbés.

Zusammenfassung. Bis vor kurzem erforderte der einzige Weg, die Verteilung und Architektur von Baumwurzeln zu untersuchen, das physische Entfernen von Boden. Doch in der letzten Dekade wurde vermehrt ein in den Boden eindringendes Radar (GPR), welches in vielen anderen Industrien seit ca. 30 Jahren bekannt ist, verwendet. GPR ist relativ neu für Australien und das Ziel dieser Studie lag darin, die räumliche Akkuresse zu untersuchen und die Fähigkeit, Wurzeln zu finden.

Es wurden drei Experimente mit dem $900 \mathrm{MHz}$ GPR Gerät (Tree Radar ${ }^{\circledR}$ ) durchgeführt. Das erste Experiment testete die Fähigkeit des GPR, Wurzeln mit der Größe $10 \mathrm{~mm}, 20 \mathrm{~mm}$, und $40 \mathrm{~mm}$ Durchmesser in einer Tiefe von $200 \mathrm{~mm}, 400 \mathrm{~mm}$, und $800 \mathrm{~mm} \mathrm{zu}$ finden, während das zweite Experiment die Kapazität untersuchte, zwei dicht neben einander wachsende Wurzeln zu klären. Das letzte Experiment verwendete GPR, um das Wurzelsystem einer kleinen Chinesischen Pistazie in situ zu analysieren, nachdem das Wurzelsystem mittels eines AirSpade ${ }^{\odot}$ aufgegraben und die Anzahl der Wurzeln gezählt wurde und verglich diese mit den vorhergesagten Resultaten.

GPR stellte dar und unterschied die Baumwurzeln akkurat bei einer Tiefe von $200 \mathrm{~mm}$, aber mit zunehmender Tiefe von $400 \mathrm{~mm}$ und später $800 \mathrm{~mm}$ nahmen die Fehler zu, wahrscheinlich wegen der Wahl der für dieses Experiment verfügbaren Antenne, was dazu führte, dass in einigen Ergebnissen Phantomwurzeln auftauchten und einige vorhandene Wurzeln nicht entdeckt wurden. Ein Verwirren der Resultate mit unerwarteten Interferenzen oder inadäquate Signalverarbeitung waren wahrscheinlich die Gründe. In dem letzten Experiment verpasste GPR viele kleine Wurzeln in den
Gräben dicht beim Baum und schien viele kleine Wurzeln als eine große zu behandeln. In den äußeren Gräben sagte GPR insgesamt 52 Wurzeln vorher, aber bei der Aufgrabung wurde an dieser Stelle nur eine Wurzel gefunden.

Resumen. Hasta hace poco la única manera de investigar la arquitectura y distribución de las raíces implicaba la remoción física de suelo. Sin embargo, en la última década, el radar de penetración terrestre (GPR), empleado en muchas otras industrias por unos 30 años, se utilizó para estudiar las raíces del árbol. El GPR es relativamente nuevo en Australia y el objetivo de esta investigación fue evaluar la precisión espacial y capacidad de detectar las raíces del árbol. Tres experimentos se llevaron a cabo utilizando un dispositivo GPR de $900 \mathrm{MHz}$ (Tree Radar ${ }^{\circ}$ ).

El primer experimento prueba la capacidad de GPR para detectar raíces de tamaños de $10 \mathrm{~mm}, 20 \mathrm{~mm}$ y $40 \mathrm{~mm}$ de diámetro a una profundidad de $200 \mathrm{~mm}, 400 \mathrm{~mm}$ y $800 \mathrm{~mm}$; mientras que el segundo experimento probó su capacidad para detectar dos raíces juntas. Las raíces de 20-30 mm de diámetro se colocaron en pares en $20 \mathrm{~mm}, 40 \mathrm{~mm}$ y $80 \mathrm{~mm}$ de separación a una profundidad de $200 \mathrm{~mm}, 400 \mathrm{~mm}$ y $800 \mathrm{~mm}$. El último experimento utiliza GPR para analizar el sistema de raíces in situ de una pequeña Pistacia chinensis (pistacho chino) después de lo cual el sistema de raíces fue excavado utilizando un AirSpade ${ }^{\bullet}$ y el conteo del número de raíces fue realizado y comparado con los resultados previstos.

GPR detectó y discriminó raíces de los árboles con precisión a $200 \mathrm{~mm}$ de profundidad, pero como la profundidad aumentó a 400 $\mathrm{mm}$ y luego a $800 \mathrm{~mm}$, los niveles de error aumentaron, probablemente debido a la elección de la antena disponible para los experimentos que conducen a la presencia de raíces fantasmas en algunos resultados y la no detección de raíces verdaderas en otros. La confusión de la señal con una interferencia inesperada o procesamiento de señal inadecuada fue la causa más probable. En el experimento final, GPR perdió muchas raíces pequeñas en las zanjas cercanas al árbol y pareció detectar múltiples raíces como una sola. En las zanjas exteriores, GPR predijo 52 raíces en total, pero la excavación reveló solamente una en estos suelos urbanos perturbados. 